\title{
Giant Cell Tumor
}

National Cancer Institute

\section{Source}

National Cancer Institute. Giant Cell Tumor. NCI Thesaurus. Code C3055.

A benign, intermediate, or malignant tumor that arises from the bone or soft tissue. It is characterized by the presence of multinucleated osteoclast-like giant cells. 